\title{
Mistifikasi Prabowo-Sandi dalam Iklan Politik
}

\section{Prabowo-Sandi's mystification in political advertising}

\author{
Safarudin \\ Pascasarjana Komunikasi Politik, Universitas Paramadina, Indonesia
}

Diterima:29 Desember 2020; Disetujui: 7 Januari 2021; Diterbitkan: 31 Januari 2021.

\begin{abstract}
Abstrak
Penelitian ini bertujuan untuk mengetahui mistifikasi pesan-pesan politik ditampilkan dalam materi kampanye pasangan calon Prabowo-Sandi pada pemilihan presiden 2019 yakni pada makna denotatif dan konotatif yang terkandung dalam iklan tersebut. Materi kampanye yang akan diteliti adalah video iklan resmi Prabowo-Sandi yang diserahkan kepada Komisi Pemilihan Umum. Penelitian ini menggunakan analisis semiotika untuk memeriksa sistem tanda pada video iklan kampanye kandidat Prabowo-Sandi pada Pemilihan Umum 2019 sebagai bagian dari komodifikasi konten melalui praktik mistifikasi. Penelitian ini menemukan beberapa bentuk mistifikasi: PrabowoSandi dicitrakan sebagai pemimpin adil yang akan membawa kesejahteraan dan figur yang menganut pluralisme, menghargai perbedaan, dan menjunjung tinggi kebhinekaan. Kondisi yang sangat berlawanan dengan keadaan objektif kandidat dan nilai yang dianut pengusung dan pendukungnya. Kesimpulan dari kajian ini yakni Iklan politik tersebut lebih dalam lagi (konotatif) memistifikasi sosok Prabowo-Sandi sebagai patriot bangsa yang akan mengentaskan masyarakat dari persoalan kebangsaan. Tidak hanya pemimpin politik, Prabowo-Sandi juga dicitrakan sebagai pemimpin kebudayaan melalui simbolisasi raja Jawa (keris dan batik motif garuda) yang menghargai keragaman kebudayaan lainnya. Kemunculan simbol-simbol adat Lombok, minangkabau, dan Bali adalah upaya mistifikasi Prabowo-Sandi sebagai figur yang memiliki perhatian terhadap keragaman kebudayaan nusantara. Selain kebudayaan, mistifikasi Prabowo-Sandi dapat dilihat melalui simbolisasi keragaman agama.

Kata Kunci: Komodifikasi; Misifikasi; Semiotika; Iklan Politik
\end{abstract}

\begin{abstract}
This study aims to determine the mystification of political messages displayed in the campaign materials for the Prabowo-Sandi candidate pair in the 2019 presidential election, namely the denotative and connotative meanings contained in the advertisement. The campaign material to be examined is the official Prabowo-Sandi advertising video which was submitted to the General Election Commission. This study uses semiotic analysis to examine the sign system in the video advertising campaign for the Prabowo - Sandi candidate in the 2019 General Election as part of the commodification of content through the practice of mystification. This research finds several forms of mystification: Prabowo-Sandi is imaged as a fair leader who will bring prosperity and a figure who adheres to pluralism, respects differences, and upholds diversity. Conditions that are very opposite to the objective circumstances of the candidate and the values held by the bearers and supporters. The conclusion of this study is that political advertising is deeper (connotative) to mystify the figure of Prabowo-Sandi as a national patriot who will lift society from national problems. Not only political leaders, Prabowo-Sandi is also imaged as a cultural leader through the symbolization of the Javanese king (keris and garuda-motif batik) who respects other cultural diversity. The emergence of traditional symbols of Lombok, Minangkabau, and Bali is an attempt to mystify Prabowo-Sandi as a figure who has concern for the cultural diversity of the archipelago. Apart from culture, Prabowo-Sandi's mystification can be seen through the symbolization of religious diversity.
\end{abstract}

Keywords: Commodification; Misification; Semiotics; Political Advertising

How to Cite: Safarudin. (2021)Mistifikasi Prabowo-Sandi dalam Iklan Politik. PERSPEKTIF, 10(1): 255-264

\begin{tabular}{lr}
\hline$*$ Corresponding author: & ISSN 2085-0328 (Print) \\
E-mail: safarudin@gmail.com & ISSN 2541-5913 (online)
\end{tabular}




\section{PENDAHULUAN}

Praktik mistifikasi kandidat semakin menjamur seiring dengan maraknya politik identitas. Fenomena ini terjadi di negaranegara demokrasi. Fukuyama (2020) menyatakan bahwa geopolitik mengalami perubahan orientasi. Saat ini poros bergeser ke arah politik berbasis identitas. Secara psikologis politik identitas bermula dari perasaan bahwa mereka memiliki nilai atau martabat batin yang kurang mendapatkan perhatian dari lingkungan sekitar. Sehingga mereka merasa mengalami marginalisasi.

Media memiliki pengaruh yang signifikan dalam meningkatnya politik identitas. Doroshenko (2018) melakukan penelitian pengaruh media terhadap meningkatnya gelombang politik identitas di Eropa dalam konteks kemenangan partai-partai kanan yang mengusung politik identitas. Penelitian menyatakan meningkatnya popularitas partaipartai sayap kanan di Eropa sejak awal abad ke21 telah terjadi bersamaan dengan adanya komersialisasi pasar media, semakin banyaknya sumber berita online, populisme media, dan mediaisasi politik.

Fokus yang disasar aktor politik identitas adalah pada upaya memunculkan emosi pemilih, bukan pada argumentasi rasional. Sebagaimana disampaikan Fukuyama (2020) bahwa identitas terkait erat dengan emosi, kesombongan, kemarahan, dan kebencian. Sehingga pemilih berada dalam kebingungan dalam melihat fakta secara objektif. Pada titik inilah mistifikasi menemukan ruangnya, melalui penyebaran pesan secara massif. Wirz (2018) melakukan penelitian untuk menguji apakah seruan politik identitas memang menimbulkan emosi dan selanjutnya meningkatkan daya tarik pesan. Penelitian dilakukan dengan membandingkan seruan politik identitas dan pluralis pada poster iklan politik. Hasilnya menunjukkan pesan politik identitas yang disajikan memunculkan emosi yang lebih kuat daripada seruan pluralis.

Mistifikasi politik seringkali dilakukan dengan basis disinformasi: pesan tidak akurat, tidak jujur, bahkan cenderung tidak benar. Hameleers (2020) melakukan analisis konten kualitatif komparatif di Amerika Serikat dan Belanda untuk memberikan pemahaman mendalam tentang konstruksi diskursif realitas dan kesalahan informasi dan disinformasi oleh politisi sayap kanan. Hasil penelitian menunjukkan bahwa baik Trump di Amerika Serikat dan Wilders di Belanda mendiskreditkan informasi ketika pesan tersebut tidak menguntungkan mereka. Pada saat yang sama, mereka menggunakan informasi, statistik, dan sumber media secara strategis ketika data-data tersebut menguntungkan.

Sementara itu Hunter dan Power (2019) meneliti fenomena politik populis pada pemilihan umum 2018 di Brazil. Jair Bolsonaro seorang kandidat yang mengusung politik identitas berhasil memenangkan pemilu. Penelitian menunjukkan bagaimana media sosial bersama dengan jaringan gereja-gereja Pentakosta menjadi agen penyebarluasan pesan-pesan Bolsonaro. Pesan-pesan populis dibalut dengan narasi agama untuk menyentuh bagian paling emosional warga. Selama kampanye Bolsonaro mengkritik dan menyerang lawan-lawan politiknya dan melakukan mistifikasi untuk menyelamatkan negara dari kehancuran total.

Penelitian-penelitian tersebut belum ada yang secara detail menjelaskan mistifikasi sebagai bagian dari komodifikasi konten dalam studi ekonomi politik media. Studi kritis secara mendalam tentang komodifikasi melalui mistifikasi pesan politik berbasis identitas juga belum banyak dilakukan. Penelitian komodifikasi konten sebagian besar hanya berfokus pada eksploitasi tubuh, gender, budaya, atau agama demi kepentingan ekonomi media an sich. Belum secara detail masuk dalam ruang tafsir pesan yang sarat dengan simbolsimbol politik.

Penelitian Fadillah (2015) menyatakan telah terjadi proses komodifikasi seksual yang dilakukan media untuk mendapatkan audiens sebanyak-banyaknya. Lebih lanjut Jungmin Kwon (2016) menyatakan bahwa media melakukan praktik komodifikasi konten terhadap kelompok gay. Penelitian menemukan peningkatan representasi tubuh gay di media arus utama Korea. Fenomena ini tidak bisa lepas dari adanya liberalisasi dan Hollywoodisasi industri film Korea dan kooptasi aktifnya terhadap fandom perempuan muda lokal untuk komoditas media gay.

Penelitian Susanti dan Rochman (2016) juga menegaskan praktik media dalam mengeksploitasi tubuh. Tubuh perempuan seringkali dikomodifikasi untuk merebut perhatian audiens. Perempuan dijadikan objek 
untuk menaklukkan pasar komersial. Tubuh dan ekspresi perempuan dieksplorasi secara massif untuk memberi berbagai kesan yang mendukung citra produk yang ditampilkan media.

Selain terhadap tubuh, tayangan media juga melakukan komodifikasi agama. Agama sebagai ruang sakral yang bersifat transendental tidak luput dari praktik jual beli kepentingan kapital. Yusuf (2016) menjelaskan komodifikasi agama telah lama merambah di televisi komersial di Indonesia. Penelitian menemukan bahwa penceramah, konten, hingga audiens agama yang semestinya berada di luar area kontestasi tak luput dari praktik komodifikasi. Sehingga konten-konten agama yang disebarluaskan media bukan dalam rangka syiar agama, melainkan untuk meraup keuntungan kapital.

Komodifikasi juga masuk dalam ruang seni dan musik. Perdana (2017) mengkaji bagaimana praktik komodifikasi terjadi dalam ajang pencarian bakat Indonesian Idol. Penelitian menemukan terjadi komodifikasi konten, komodifikasi pekerja, dan komodifikasi audiens. Selain itu juga terjadi perluasan komodifikasi dan komodifikasi imanen.

Praktik komodifikasi juga terjadi di media sosial. Penelitian Shtern dkk (2019) membahas masalah yang terkait dengan monetisasi di platform media sosial melalui penyelidikan pengaruh media sosial di Filipina. Berdasarkan serangkaian wawancara dengan influencer Filipina, peneliti menemukan bagaimana influencer memahami, melibatkan, dan mengkomodifikasi penonton untuk konten mereka.

Studi tentang komodifikasi konten melalui praktik mistifikasi politik akan lebih mendalam jika menggunakan analisis semiotika. Terlebih studi ini ingin mengetahui makna pesan dalam iklan politik PrabowoSandi dalam kampanye pemilu 2019. Barthes (1995) menjelaskan dunia ini penuh dengan tanda-tanda. Iklan merupakan kumpulan simbol, gambar, kata-kata, suara yang mengandung makna berlapis, menawarkan wawasan penting ke dalam budaya, subkultur, dan ideologi dominan. Pemaknaan terhadap tanda sangat bergantung pada latar belakang sosio-kultural orang yang menafsiri tanda tersebut.

Kajian semiotika kampanye politik telah banyak dilakukan, Nawawy dan Nasry (2016) melakukan studi semiotika pada materi kampanye calon presiden Mesir Al Sissi. Penelitian tersebut mengungkap bagaimana $\mathrm{Al}$ Sissi yang memiliki latar belakang negatif dalam proses demokrasi di Mesir dimistifikasi sebagai seorang pahlawan demokrasi yang menyelamatkan rakyat Mesir. Melalui baliho dan iklan-iklan politik di media lainnya Al Sissi yang dicitrakan sebagai seorang pahlawan akhirnya mampu merebut simpati rakyat Mesir dan memenangkan pemilihan presiden. Kondisi tersebut hampir mirip dengan latar belakang Prabowo Subianto yang lekat dengan isu pelanggaran HAM namun dalam kampanye selalu dibranding sebagai sosok nasionalis dan patriotis. Prabowo tidak memiliki latar belakang keislaman yang kuat, namun dalam proses kampanye selalu dicitrakan sebagai representasi ulama.

McIlwain (2007) melakukan studi semiotika terhadap iklan politik David Perryman yang ditayangkan di televisi dalam pemilihan anggota kongres di Oklahoma. Penelitian ini menjelaskan bagaimana iklan politik David Perryman secara konotatif memiliki makna yang sarat dengan rasisme. Hal ini digunakan untuk menyerang J.C. Watts rival politiknya yang berkulit hitam. Merujuk pada konsepsi Roland Barthes tentang semiotika kritis, penelitian ini menyelidiki sistem tanda di iklan yang berupa foto, bahasa tertulis, bahasa lisan, dan gambar bergerak. Analisis menunjukkan, bagaimana iklan tersebut menentang pencalonan Watts secara implisit dan memberikan pesan kepada pemilih bahwa kulit hitam identik dengan sifat rendah diri, inferior, kriminal, dan persepsi tentang gerakan kebangkitan kulit hitam.

Studi tentang kampanye Prabowo juga telah dilakukan Halim dan Widayatmoko (2015) penelitian mengupas representasi citra Prabowo dalam pemilihan presiden 2014. Bagaimana karakter Prabowo dengan tagline macan Asia direpresentasikan melalui video game. Herpamudji (2015) meneliti tentang strategi kampanye politik Prabowo Subianto melawan Joko Widodo pada pemilihan 2014. Penelitian ini secara rinci menguraikan strategi yang dilakukan Prabowo Subianto dalam pencitraan secara massif di media massa dalam merebut perhatian pemilih. Prabowo dibranding sebagai sosok nasionalis yang identik dengan simbol-simbol Soekarno. Penelitian ini berfokus pada bagaimana strategi 
kampanye disusun dan dijalankan di media massa, tidak secara khusus meneliti secara mendalam makna simbol-simbol nasionalis dikonstruksi dalam setiap pesan yang disampaikan.

Berangkat dari pembacaan atas penelitian-penelitian diatas, penelitian ini akan berfokus pada bagaimana mistifikasi pesanpesan politik ditampilkan dalam materi kampanye pasangan calon Prabowo-Sandi pada pemilihan presiden 2019. Penelitian akan berusaha mengetahui makna denotatif dan konotatif yang terkandung dalam iklan tersebut. Materi kampanye yang akan diteliti adalah video iklan resmi Prabowo-Sandi yang diserahkan kepada Komisi Pemilihan Umum.

\section{METODE PENELITIAN}

Penelitian ini menggunakan pendekatan kualitatif dengan paradigma kritis. Penelitian dengan pendekatan kualitatif digunakan untuk menjawab pertanyaan tentang apa, bagaimana atau mengapa terhadap sebuah permasalahan sosial, berbeda dengan pendekatan kuantitatif yang cenderung digunakan untuk menjawab pertanyaan berapa banyak (McCusker dan Gunaydin, 2015). Penelitian menggunakan analisis semiotika. Analisis semiotika akan mampu mengurai rumusan masalah penelitian dimana untuk mengetahui bagaimana makna pesan mistifikasi politik dalam iklan politik Prabowo-Sandi. Analisis semiotika lebih tepat digunakan untuk membedah konten iklan politik dengan format video daripada analisis isi, framing, atau wacana.

Peneliti menggunakan analisis semiotika Roland Barthes untuk mengetahui dan mendeskripsikan bentuk-bentuk mistifikasi yang terkandung dalam iklan politik PrabowoSandi. Secara sistematis akan diuraikan makna denotatif dan makna konotatif dari tanda-tanda di dalam iklan tersebut.

Penelitian ini bersifat deskriptif dan eksploratif. Peneliti akan mengeksplorasi makna pesan yang menjadi konten mistifikasi politik. Setelah itu peneliti secara detail akan mendeskripsikan bagaimana makna pesan tersebut muncul. Secara garis besar penelitian akan mencari apa saja bentuk-bentuk mistifikasi politik yang terkandung dalam iklan politik Prabowo-Sandi. Kemudian peneliti akan menjelaskan bagaimana makna pesan tersebut secara mendalam.
Sumber data dalam penelitian ini didapat dari video kampanye pasangan calon nomor urut 02 Prabowo - Sandi yang diunggah di channel youtube KPU RI pada tanggal 25 Maret 2019. Peneliti mengunduh video tersebut pada tanggal 10 Januari 2020. Selain itu video tersebut juga diupload di akun instagram resmi Prabowo Subianto pada tanggal 24 Maret 2019 dengan caption "Bersama Prabowo-Sandi, Indonesiaku Adil dan Makmur \#negerielokamatkucinta". Selain itu peneliti juga mengumpulkan data-data sekunder yang mendukung objek penelitian, berupa artikel, berita, literatur dan dokumentasi sosial media.

Teknik pengumpulan data dalam penelitian ini adalah dokumentasi. Metode analisis data yang akan digunakan adalah metode analisis deskriptif kualitatif. Metode yang dimaksud adalah dengan mengolah data yang diperoleh sedemikian rupa, menganalisa dan menginterpretasikan sehingga diperoleh jawaban yang tepat dari permasalahan yang dipaparkan.

Analisis semiotika bersifat interpretif. Pendekatan dalam penelitian ini bisa sangat subjektif dan memiliki hasil yang sangat relatif. Sebagaimana disampaikan Griffin (1991) bahwa ada dua pendekatan dalam perkembangan teori komunikasi sebagai bagian dari ilmu sosial, yaitu objective approach dan interpretive approach. Objective approach berasumsi bahwa kebenaran itu tunggal dan dapat diakses melalui pengamatan indera yang tidak memihak dan berkomitmen untuk mengungkap hubungan sebab-akibat. Sedangkan interpretive approach berasumsi bahwa kebenaran sosial adalah relatif dan interpretatif. Terlebih ketika melakukan penelitian linguistik ataupun semiotika.

Peneliti menyadari bahwa dalam melakukan analisis semiotika terhadap pesan verbal dan nonverbal subjektivitas tidak bisa dihindarkan. Karena sebagaimana pemahaman dalam tradisi semiotika bahwa tafsir terhadap suatu simbol akan bergantung pada bagasi pengetahuan dan latar belakang sosial penafsir. Sehingga tidak ada tafsir tunggal dalam memaknai suatu pesan.

Kunci dalam penelitian kualitatif khususnya semiotika terletak pada proses metodologinya. Sehingga peneliti harus benarbenar memastikan bahwa proses penyusunan metodolgi sudah sesuai dan analisis dilakukan sesuai dengan metodologi yang telah 
ditentukan. Hal ini menjadi kunci keabsahan penelitian yang dilakukan.

\section{HASIL DAN PEMBAHASAN}

Iklan politik Prabowo - Sandi dalam penelitian ini berbentuk video dengan durasi 30 detik. Iklan tersebut merupakan materi resmi yang diserahkan BPN 02 ke Komisi Pemilihan Umum. Video diawali dengan kemunculan Prabowo-Sandi yang mengenakan setelan jas lengkap dan mengenakan peci hitam. Kemudian ditampilkan keindahan alam Indonesia, dilanjutkan dengan keragaman budaya, agama, seni, dan profesi masyarakat Indonesia. Ditampilkan juga Prabowo-Sandi yang sedang turun di tengah masyarakat. Setelah itu ditampilkan gambaran kesuburan tanah air Indonesia dan menampilkan Prabowo-Sandi dengan pose hormat. Di akhir video ada narasi Prabowo yang berbunyi "Tanah yang subur, cita-cita yang luhur, bersama Prabowo-Sandi Indonesiaku adil dan makmur". Video ditutup dengan kibaran bendera merah putih. Sepanjang iklan diiringi soundtrack musik instrumental rayuan pulau kelapa.

Peneliti mengambil beberapa bagian (screenshot) dari iklan tersebut dalam kaitannya terhadap mistifikasi yang menjadi fokus dalam penelitian ini. Bagian-bagian tersebut peneliti sajikan sebagai berikut.

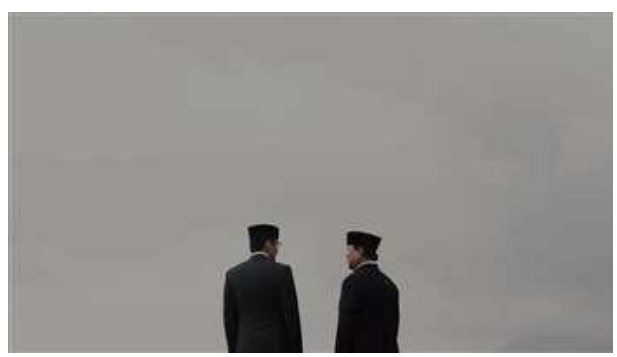

Gambar 3. Prabowo-Sandi

Pada bagian pembuka ditampilkan Prabowo-Sandi yang sedang memunggungi kamera. Keduanya menggunakan jas hitam dan peci. Keduanya nampak sedang berbincang dengan latar langit yang sedang mendung dengan warna abu-abu. Diiringi dengan musik instrumental rayuan pulau kelapa. Bagian ini ditampilkan dengan durasi 2 detik. Gambaran ini merupakan makna denotatif. Gambaran yang terlihat secara eksplisit.
Secara konotatif penggunaan jas dan peci hitam merupakan simbolisasi sebagai pakaian resmi pemimpin nasional. Peci merupakan identitas nasional. Peci juga merupakan simbol yang identik dengan para pendiri bangsa, khususnya Soekarno. Dengan menggunakan peci hitam, Prabowo-Sandi ingin menyampaikan bahwa mereka merupakan pemimpin nasional yang akan mempersatukan seluruh elemen masyarakat yang beragam. Latar belakang mendung dan warna abu-abu memiliki arti kondisi negeri saat ini. Pesan yang disampaikan adalah bahwa sampai hari ini situasi Indonesia masih mendung, dirundung banyak persoalan. Persoalan pengangguran, kemiskinan, pertumbuhan ekonomi, kesenjangan sosial, ketidakadilan hukum, korupsi, pendidikan dan kesehatan yang tidak bisa diakses masyarakat bawah, tingginya hutang pemerintah merupakan persoalanpersoalan yang disimbolkan dalam visualisasi latar belakang mendung.

\section{Mistifikasi Budaya}

Visualisasi keragaman suku dan kebudayan melalui gambaran pusaka adat dan bela diri. Pada bagian ini ditampilkan seorang laki-laki dengan pakaian adat jawa sedang menaruh keris di pinggul bagian belakang. Terlihat laki-laki tersebut mengenakan batik motif garuda. Lalu dilanjutkan dengan adegan peresean. Sebuah tradisi adu kejantanan antara dua orang laki-laki dalam tradisi Sasak.

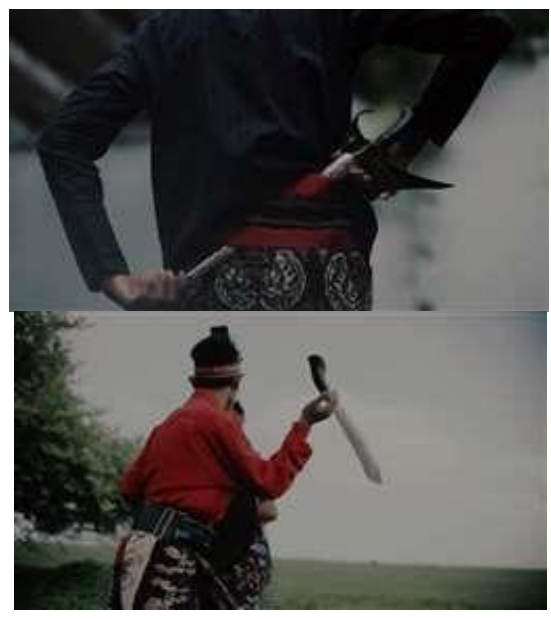

Gambar 4. Pusaka Adat Jawa dan Sasak

Secara konotatif bagian ini ingin menyampaikan pesan keragaman tradisi dan adat istiadat masyarakat Indonesia, kemunculan adat Jawa bermakna: 


\section{Jawa}

Simbolisasi Jawa sangat penting dalam konteks pemilu di Indonesia. Bahkan sampai ada rumus, selain orang jawa tidak akan mungkin bisa menjadi presiden di Indonesia. Maka untuk menggambarkan keragaman budaya di Indonesia, pertama kali yang ditampilkan dalam iklan tersebut adalah gambaran adat Jawa.

\section{Keris}

Keris merupakan pusaka dalam tradisi Jawa. Keris bukan hanya senjata, tapi lebih dari itu keris merupakan simbol kehormatan lakilaki Jawa. Keris hanya digunakan dalam perang sebagai senjata pamungkas. Siswanto (2012) dalam penelitiannya menyatakan keris dalam tradisi jawa tidak hanya berdimensi horizontal imanen tetapi juga berdimensi transendenvertikal. Dalam konteks pemilihan umum, kemunculan keris dalam iklan tersebut bermakna kesiapan Prabowo untuk mengeluarkan pusaka pamungkasnya dalam menghadapi pertempuran pemilihan presiden 2019.

3. Batik motif garuda

Motif batik garuda dalam tradisi Mataram hanya dikenakan oleh Raja. Dalam agama Hindu, garuda merupakan kendaraan dari dewa Wisnu. Dewa Wisnu merupakan dewa matahari sehingga dilambangkan sebagai sumber kehidupan utama dan kejantanan. Sehingga diharapkan sorang Raja dapat menerangi kehidupan dunia (Indriani 2015).

Pesan ini secara implisit menyampaikan bahwa Prabowo mengidentifikasi sebagai raja Jawa. Sehingga dia berhak atas kursi presiden yang sedang diperebutkan. Tujuan dia menduduki kursi kepresidenan adalah dalam rangka mengantarkan masyarakat Indonesia menuju keadilan dan kemakmuran. Sebagaimana makna garuda dalam tradisi hindu.

Tradisi Peresean dalam iklan tersebut bermakna sebuah pertarungan adu kejantanan antara dua orang laki-laki. Tradisi ini merupakan tradisi turun temurun masyarakat Sasak. Simbolisasi peresean bermakna pertarungan antara Jokowi dan Prabowo yang sedang beradu kekuatan politik.

Keragaman yang ditampilkan selanjutnya adalah seni tari-tarian daerah. Pertama adalah tarian piriang atau tari piring dari Minangkabau. Dimana ditampilkan dua orang perempaun sedang berhadapan dengan baju adat minangkabau sedang menari piring. Pertunjukkan adat Minangkabau tidak bisa dilepaskan dengan fakta bahwa Prabowo memiliki basis pemilih yang kuat di masyarakat Minang. Tari piring merupakan upacara adat sebagai simbol syukuran setelah panen. Tarian dilakukan dengan membawa sesaji di dalam piring dan melangkah secara beriringan.

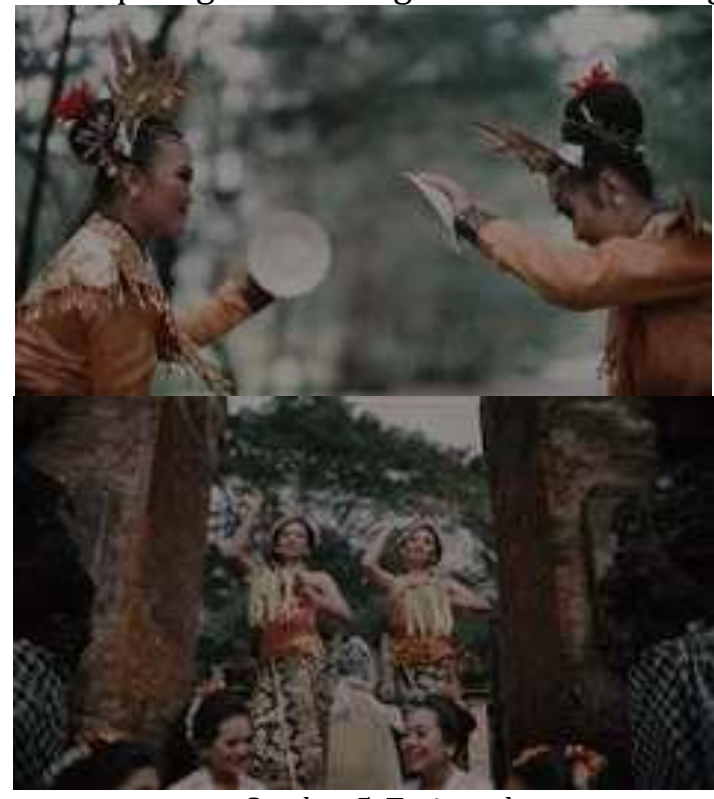

Gambar 5. Tarian adat

Simbolisasi keragaman kebudayaan selanjutnya adalah tari pendet dari Bali. Bali sebagai barometer kebudayaan Hindu di Indonesia ditampilkan dalam adegan dua orang penari di tengah perkumpulan pertunjukan. Astini dan Utina (2007) menjelaskan bahwa pendet termasuk jenis tarian Bali yang memiliki susunan gerakan sederhana. Pendet tergolong ke dalam jenis tarian sakral yang pelaksanaannya di tempat ibadah. Tari pendet sebagai lambang penyambutan turunya para dewata ke dunia. Sedangkan fungsinya adalah sebagai simbol ucapan selamat datang kepada para dewa yang turun ke dunia.

\section{Mistifikasi Agama}

Pada bagian ini ditampilkan simbolsimbol agama di Indonesia. Scene pertama yang ditampilkan adalah gambaran perempuan yang sedang beribadah dalam agama Hindu dan Budha. Dengan setting di tempat ibadah di waktu fajar, sesaat sebelum matahari terbit. Scene ini hanya berdurasi masing-masing 1 detik. Sebagaimana scene sebelumnya pada bagian ini masih diiringi musik instrumental rayuan pulau kelapa. 


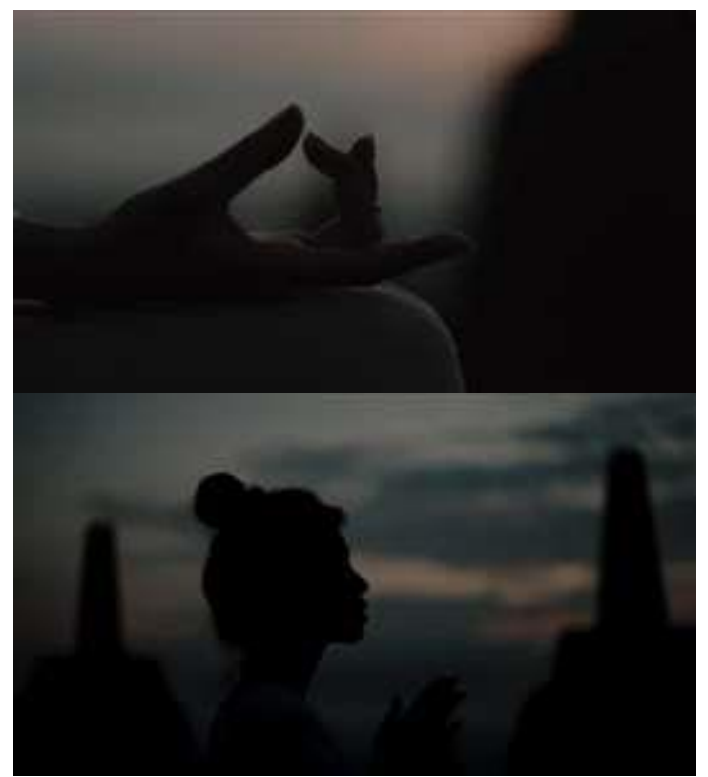

Gambar 6. Simbolisasi Hindu-Budha

Hindu dan Budha sebagai agama yang pertama kali datang ke nusantara ditampilkan terlebih dahulu. Dengan menampilkan setting di sebuah candi sebagai warisan para leluhur, iklan ini hendak mengajak kita mengenang kembali kejayaan nusantara pada masa HinduBudha. Sebagaimana ketika era kerajaan Mataram Kuno, Sriwijaya, dan Majapahit. Agama Hindu dan Budha merupakan ajaran tentang kehidupan yang harmoni.

Wayan Sukabawa (2019) menjelaskan Inti ajaran Hindu dikonsepkan kedalam tiga kerangka dasar yang terdiri dari tattwa (filsafat) susila (etika)

dan upacara (yadnya). Maka pesan yang disampaikan Prabowo secara implisit dalam konteks kampanye pemilihan umum 2019 adalah pentingnya tattwa menjadi manusia Indonesia yang rasional, bersusila dalam hubungan sosial, dan selalu menjadi makhluk transenden melalui ibadah kepada Tuhan.

Konsep ketuhanan dalam agama Buddha berbedadengan konsep agama Samawi dimana alam semesta diciptakan oleh Tuhan dan tujuan akhir dari hidup manusia adalah kembali ke surga ciptaan Tuhan sing kekal (Taufik, 2016). Agama Budha mempercayai adanya reinkarnasi, suatu proses perbaikan kehidupan akibat karma di kehidupan sebelumnya. Proses reinkarnasi berhenti sampai dengan manusia bisa mencapai moksa.

Visualisasi berikutnya adalah gambaran seorang umat kristen yang sedang menengadah, simbol kalung salib, dan lilin.
Laki-laki menengadah ke atas dan dengan latar cahaya yang muncul dari langit-langit. Sebuah simbol pencerahan, gambaran dari seorang laki-laki yang sedang di ruang gelap melambangkan bahwa manusia merupakan domba yang tersesat. Dia selalu membutuhkan cahaya untuk mencapai jalan kebenaran. Sedangkan gambar yang kedua sumber cahaya berasal dari lilin. Keduanya merupakan simbol petunjuk dari dzat yang maha kasih.

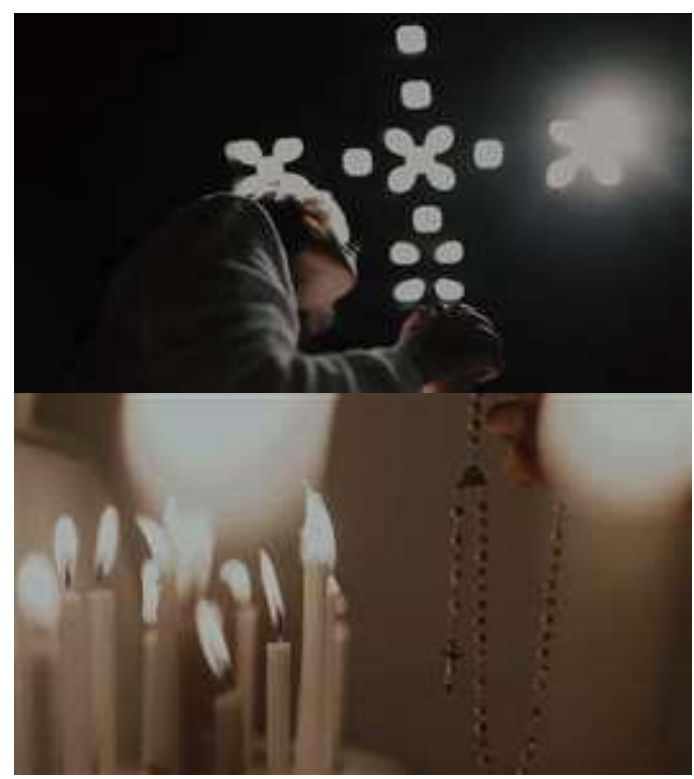

Gambar 7. Simbolisasi Kristen-Katholik

Sari (2018) menerangkan bahwa salib merupakan simbol identitas umat kristiani. Simbol salib digunakan setiap upacara peribadatan. Meskipun pada mulanya salib bukanlah simbol umat kristiani, simbol salib sudah muncul sebelum kristen ada. Bahkan pada mulanya salib merupakan simbol kehinaan dalam tradisi kristen karena Yesus kristus dihukum di papan salib. Secara historis peristiwa penyaliban Yesus dimodifikasi sebagai simbol pengorbanan dan kasih sayang seorang Yesus. Bentuk salib dalam video iklan tersebut adalah salib crix immisa, bentuk salib dengan bagian bawah lebih panjang. Salib model ini yang dipercaya digunakan untuk menyalib Yesus.

Perjalanan sejarah telah menggeser pemaknaan terhadap salib. Salib tidak lagi dimaknai sebagai alat penyiksa Yesus, namun sebaliknya sebagai sebuah simbolisasi bahwa Yesus telah disalib dengan tujuan membebaskan manusia dari dosa turunan. Sehingga salib bukan hanya sebagai kayu yang 
tersilang yang digunakan untuk menyiksa, lebih dari itu sebagai simbol kekuatan Tuhan yang rela menderita demi untuk meneyelamatkan manusia (Sari, 2018).

Penggunaan simbol salib dalam iklan Prabowo-Sandi tidak hanya bermakna sebatas pluralisme agama. Lebih dari itu pesan yang muncul adalah keteladanan seorang pemimpin yang rela mengorbankan dirinya untuk kesejahteraan rakyatnya. Seorang pemimpin harus melindungi hak hidup warganya, meskipun dia harus kehilangan nyawanya. Selain itu salib sebagai simbol agama kristen mendasarkan ajarannya pada nilai kasih sayang. Seorang pemimpin haruslah melihat rakyatnya dengan kaca mata kasih sayang. Sehingga tidak ada lagi melihat rakyat yang bukan pendukungnya sebagai musuh ataupun ancaman bagi keberlangsungan jabatan yang sedang dia emban.

Simbol terakhir yang muncul dalam iklan tersebut adalah simbol-simbol yang merepresentasikan keislaman. Berbeda dengan scene agama sebelumnya yang hanya dimunculkan dalam satu adegan, simbol agama Islam ditampilkan dalam 3 potongan adegan. Pertama, simbol seorang laki-laki sedang memukul bedug, dengan latar belakang langit biru cerah dengan kombinasi awan. Kedua, adegan seorang laki-laki berkumis dan berjenggot sedang berwudlu dengan membasuh muka. Ketiga, seorang laki-laki berpakaian putih, peci putih, bersarung kotakkotak sedang mendirikan sholat. Nampak, dia sedang melakukan gerakan ruku' dan bangkit dari ruku' atau i'tidal.
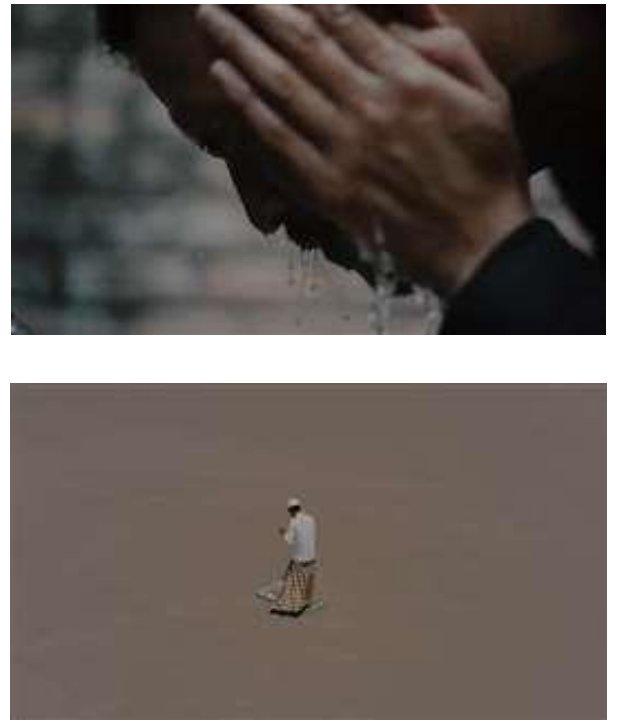

Gambar 8. Simbolisasi Islam
Islam sebagai agama mayoritas di Indonesia diberikan durasi yang lebih banyak ketimbang simbol-simbol agama yang muncul simbulnya. Padahal dengan durasi yang ada sebenarnya akan lebih ideal jika durasi tersebut digunakan untuk menampilkan agama atau aliran kepercayaan yang lainnya yang tumbuh dan berkembang di Indonesia. Karena sebagaimana kita ketahui Konghucu juga merupakan agama yang secara resmi telah diakui oleh pemerintah. Disamping aliranaliran kepercayaan yang telah lama dianut oleh masyarakat nusantara yang juga dijamin keberadaannya oleh undag-undang.

Penayangan simbol-simbol islam dengan porsi yang lebih besar juga bisa dimaknai sebagai salah satu upaya Prabowo-Sandi dalam merebut pemilih muslim, yang notabene merupakan pemilih terbesar pada pemilu 2019. Simbol keislaman yang ditampilkan dalam iklan merupakan Islam dengan karakteristik Indonesia atau Islam tradisional. Hal ini bisa dilihat dari adanya bedug dan sarung. Bedug dan sarung merupakan simbol keislaman khas Indonesia. Keduanya bahkan identik dengan simbol-simbol komunitas nahdliyin, suatu komunitas terbesar di Indonesia (Nurjaman, 2017). Keanggotan dan afiliasi masyarakat terhadap nahdliyin yang begitu besar menjadi magnet elektoral bagi pasangan PrabowoSandi.

Aziz (2013) menerangkan bahwa bedug merupakan hasil akulturasi nilai-nilai agama dan budaya. Bedug sebagai penanda panggilan sholat oleh para penyebar agama disandingkan dengan adzan yang secara fiqh merupakan panggilan untuk mendirikan sholat. Keberadaan bedug tidak menggantikan fungsi adzan, tetapi sebagai media komplementer yang selama ini telah digunakan oleh masyarakat Indonesia.

Sebagaimana disampaikan diatas, kemunculan bedug dan sarung merupakan salah satu upaya Prabowo-Sandi dalam menarik pemilih Islam tradisional atau nahdliyin. Sebagaimana kita ketahui mayoritas kelompok islam yang berada di barisan pendukung Prabowo-Sandi adalah kelompok Islam modern dan kelompok Islam puritan. Selain itu keberadaan KH Maruf Amin yang merupakan Rais Aam organisasi Nahdlatul Ulama semakin memberatkan Prabowo dalam meraih suara kaum nahdliyin. 
Penggunaan simbol bedug dan sarung bisa menjadi paradoks, karena kelompokkelompok Islam garis kanan mayoritas mendukung prabowo. Kelompok-kelompok tersebut yang secara nilai seringkali berseberangan dengan faham islam tradisional. Bahkan dalam tataran tertentu di kelompok islam kanan, bedug dianggap sebagai bid'ah. Suatu produk yang tidak ada dalil dan contoh pada zaman nabi. Secara umum simbolisasi agama Islam hendak menyampaikan pesan bahwa kandidat merupakan figur pemimpin yang memiliki nilai-nilai transendental (hablumminallah) yang akan menjaga keseimbangan sosial (hablumminannas) dan lingkungan (hablumminal'alam).

\section{SIMPULAN}

Iklan politik calon presiden dan wakil presiden Prabowo-Sandi secara denotatif menyampaikan pesan bahwa Prabowo-Sandi adalah figur pluralis. Selain itu juga menegaskan bahwa Prabowo-Sandi adalah figur ideal yang akan menyelesaikan persoalan kebangsaan. Prabowo-Sandi adalah kandidat yang akan membawa keadilan dan kemakmuran bagi Indonesia. Berbeda dengan realitas objektif di lapangan dan media sosial yang sarat akan politisasi agama dan eksploitasi perbedaan ras, suku, dan antargolongan.

Iklan politik tersebut lebih dalam lagi (konotatif) memistifikasi sosok Prabowo-Sandi sebagai patriot bangsa yang akan mengentaskan masyarakat dari persoalan kebangsaan. Tidak hanya pemimpin politik, Prabowo-Sandi juga dicitrakan sebagai pemimpin kebudayaan melalui simbolisasi raja Jawa (keris dan batik motif garuda) yang menghargai keragaman kebudayaan lainnya. Kemunculan simbol-simbol adat Lombok, minangkabau, dan Bali adalah upaya mistifikasi Prabowo-Sandi sebagai figur yang memiliki perhatian terhadap keragaman kebudayaan nusantara.

Selain kebudayaan, mistifikasi PrabowoSandi dapat dilihat melalui simbolisasi keragaman agama. Simbol Hindu-Budha bermakna bahwa Prabowo-Sandi figur penjaga harmoni yang memiliki karakter tatwa (rasional), susila (bermoral), dan upacara (bertuhan). Simbol Kristen-Katholik bermakna pengorbanan seorang pemimpin dan kasih bagi rakyatnya. Sehingga Prabowo-Sandi adalah figur yang rela mengorbankan dirinya untuk kesejahteraan rakyatnya dan selalu memandang rakyat dengan kaca mata kasih sayang. Simbol Islam bermakna PrabowoSandi adalah figur pemimpin yang memiliki nilai-nilai transendental (hablumminallah) yang akan menjaga keseimbangan sosial (hablumminannas) dan lingkungan (hablumminal'alam).

Makna yang muncul dari iklan tersebut hampir bertolak belakang dengan kondisi objektif kandidat. Sebagaimana kita ketahui bahwa Prabowo adalah bagian dari rezim Orde Baru yang korup dan otoriter. Bahkan terindikasi terlibat dalam pelanggaran HAM berat. Sebagaimana mistifikasi dalam produk kapitalis, nilai-nilai tersebut tidak lebih dari sekedar citra yang dilekatkan dalam produk politik. Sehingga pemilih akan menganggap bahwa nilai-nilai tersebut (image) adalah bagian yang inheren dari kandidat. Pemilih yang tidak bisa membedakan citra dengan realitas objektif akan menjadikan hal tersebut sebagai fetissehingga muncul fanatisme berlebihan. Pada akhirnya mereka akan terkungkung dalam kesadaran palsu.

\section{DAFTAR PUSTAKA}

Astini, S.M., dan Utina, U.T., (2007). Tari Pendet sebagai Tari Balih-Balihan. Journal of Arts Research and Education, 8(2), 170-179. doi:10.15294/harmonia.v8i2.789

Aziz, D.K., (2013). Akulturasi Islam dan Budaya Jawa. Jurnal Fikrah, 1(2), 253-286

Doroshenko, L., (2018). Far-Right Parties in the European Union and Media Populism: A Comparative Analysis of 10 Countries During European Parliament Elections. International Journal of Communication, Vol 12, 31863206

ElNawawy, M. dan ElMasry, H., (2016). The Signs of a Strongman: A Semiotic and Discourse Analysis of Abdelfattah Al-Sisi's Egyptian Presidential Campaign. International Journal of Communication, 10, 2275-2296

Fadillah, D., (2015) Komodifikasi Seksual dalam Kepentingan Ekonomi Portal Berita Online. Jurnal Informasi, Vol 45 (2), 155-162

Fukuyama, F., (2020). 30 Years of World Politics: What has changed? Journal of Democracy, Volume 31, 11-21

Halim, J., dan Widayatmoko (2015). Representasi Kampanye Politik Pemilu 2014 dalam Game (Analisis Semiotik Dalam Game Jokowi Go! dan Game Prabowo The Asian Tiger). Jurnal Komunikasi UNTAR 7(2), 98 - 107. 
Hameleers, M., (20200 My Reality Is More Truthful Than Yours: Radical Right-Wing Politicians' and Citizens' Construction of "Fake" and "Truthfulness" on Social Media EvidenceFrom the United States and The Netherlands. International Journal of Communication, Volume 14, 1135-1152

Herpamudji, D.H. (2015). Strategi Kampanye Politik Prabowo-Hattadan Perang Pencitraan di Media Massa Dalam Pemilu Presiden 2014. Politika, 6(1).

Hunter, W., andPower, T.J., (2019). Bolsonaro and Brazil's Illiberal Backlash. Journal of Democracy, Volume 30, 68-82

Indriani, L., (2015). Makna Filosofi Batik.https://www.museumbatik.com/artik el/2015/05/13/Makna-Filosofi-dan-Ceritadi-Balik-Berbagai-Motif-batik---seriGurdo.html

Kwong, J., (2016). Co-mmodifying the Gay Body: Globalization, the Film Industry, and Female Prosumers in the Contemporary Korean Mediascape. International Journal of Communication Vol. 10, 1563-1580

Mosco, V., (2009) The Political Economy of Communication (2nd ed). London: Sage Publications.

McIlwain, C.D. (2007). Race, pigskin and politics: A Semiotic Analysis of Racial Images in Political Advertising. Semiotica, 167(1/4), 169-191. doi:10.1515/SEM.2007.075

McCusker, K., \& Gunaydin, S. (2015). Research using qualitative, quantitative or mixed methods and choice based on the research. Perfusion. doi: $10.1177 / 0267659114559116$

Nurjaman, A., (2017). Cleavage Agama di Tingkat Lokal Indonesia: Identifikasi Partai Tanpa
Komitmen Electoral. Jurnal Sospol UMM, 3(2), 43-66. doi: 10.22219/sospol.v3i2.5065

Perdana, D.D., (2017). Komodifikasi dalam Tayangan Televisi: Kajian Terhadap Program Indonesian Idol 2014. Jurnal Professional, Vol. 4 (1), 12-21

Sari, L.M., (2018). Simbol Salib dalam Agama Kristen. Jurnal Religi, 14(2), 155-168

Shtern, J., Hill, S., and Chan, D., (2019). Social Media Influence: Performative Authenticity and the Relational Work of Audience Commodification in the Philippines. International Journal of Communication Vol.13, 1939-1958

Siswanto, N., (2012). Metafisika Simbol Keris Jawa. Jurnal Filsafat UGM, 22(1), 69-89.

Sukabawa, I.W., (2019). Asas-Asas Kepemimpinan Hindu dalam Lontar Niti Raja Sasana. Jurnal Penelitian Agama Hindu, 3(2), 135-143

Susanti, D.K.L.R., (2016). Analisis Terhadap Komodifikasi Komodifikasi Tubuh Perempuan Dalam Iklan Es Krim Magnum Versi Pink \& Black. Jurnal Komunika, Vol. 10 (2), 201-218

Taufik, T.T. (2016). Sejarah Perkembangan Agama Buddha Nichiren Shoshu Indonesia dan Pelayanan Hak-Hak Sipil di Yogyakarta. Jurnal Religi, 12(1), 103-120 doi: 10.14421/rejusta.2016.1201-06

Wirz, D.S. Persuasion Through Emotion? An Experimental Test of the Emotion-Eliciting Nature of Populist Communication. International Journal of Communication, Vol. $12,1114-1138$

Yusuf, M.F., (2016). Komodifikasi: Cermin Retak Agama di Televisi: Perspektif Ekonomi Politik Media Interdisciplinary Journal of Communication, Vol. 1 (1), 25-42 